\title{
Management Model of Tourism Destinations Community Based
}

\author{
Fenny Thresia, Achyani, Rasuane Noor, Sumiyatun \\ \{fenny.thresia@yahoo.com ${ }^{1}$, acysbd@gmail.com ${ }^{2}$, rasuanenoor@gmail.com ${ }^{3}$, sumiyatun@gmail.com $\left.{ }^{4}\right\}$ \\ English Education, Universitas Muhammadiyah Metro, Lampung, Indonesia ${ }^{1}$, Biology Education, \\ Universitas Muhammadiyah Metro, Lampung, Indonesia ${ }^{2,3}$, History Education, Universitas \\ Muhammadiyah Metro, Lampung, Indonesia ${ }^{4}$
}

\begin{abstract}
The tourism industry is an industry that provides a lot of employment and foreign exchange. This led to the need for the tourism industry to be developed in Indonesia. The enactment of Law No. 22 of 1999 concerning Regional Government and Financial Balance between Central and Regional, has caused tourism development to be a shared responsibility between the central government and regional governments. The local government must be able to manage the tourism area with the limited human resources by the local government. Therefore, a pattern of management of tourism destinations community-based was developed. One tourism destination that was successfully developed by community groups is the Ngalgelaran tourism village. This research is interested in further researching the success of community groups in developing Nglaghelaran tourism villages.
\end{abstract}

Keywords: community, groups destinations, local governments, management, tourism.

\section{Introduction}

The tourism industry is one of the biggest foreign exchange earners for Indonesian government. Based on BPS data in 2007 and 2009, tourism is the third largest foreign exchange contributor after oil, gas, and palm oil. According to a BPS / Ministry of Tourism source, in 2010 the tourism sector's contribution to GDP was 261.05 Trillion to 461.36 Trillion rupiah. The contribution of the tourism sector to foreign exchange amounted to 7,603.45 million dollars in 2010 to $12,225.89$ million dollars in 2015 and the contribution to employment of 4 million people in 2010 to 12.1 million people or $10.6 \%$ of the total national workforce .

The tourism service industry is one of the fastest growing economic sectors in the world [1]. The tourism industry promises to open employment, community income and improve the quality of society. Therefore, many countries are trying to develop the tourism industry so that it can become a source of foreign exchange for the country. Indonesia is one of the countries that are trying to develop the tourism industry as a major source of foreign exchange.

Seeing the results obtained from the tourism industry, the development of the tourism industry deserves attention. The enactment of Law No. 22 of 1999 concerning Regional Government and Financial Balance between Central and Regional, has caused tourism development to be a shared responsibility between the central government and regional 
governments. The regional government as the holder of regional authority and authority is certainly more responsible for understanding the potential of the region. Local governments must be able to precisely determine tourism objects in the area that have the potential to be developed.

Some local governments rely on community participation in developing tourist destinations in their regions. One of them is by developing tourism awareness groups (pokdarwis) at each tourist destination. Pokdarwis spearheads the development of tourist areas in each region. One of the pokdarwis who succeeded in developing tourist areas became a favorite tourist area was the pokdarwis of Nglaghelaran village in Jogjakarta.

This study was interested in further researching the village of Nglaghelaran Pokdarwis in managing the tourism area. Researchers are also interested in examining the patterns of local government relations with Pokdarwis in managing tourism areas. The purpose of this study is that the success of the Nglaghelaran 's Pokdarwis can be replicated by Pokdarwis in other regions in Indonesia.

\section{Method}

This research was conducted using qualitative methods. In qualitative methods the data is collected by interview and observation methods. Interviews and observations were conducted on the sample of respondents selected by the researcher. The selection of respondents was done by purposive random sampling method. The sample is selected by considering the type of data to be revealed. Based on the purposive random sampling technique, the subjects selected were the Yogyakarta tourism service and the chairman of ancient volcano nglaghelaran pokdarwis. The selected subjects will be used to obtain data regarding the management of community-based tourist destinations.

\section{$3 \quad 3$ Results and Analysis}

The interviews were conducted directly with the head of the tourism service and tourism awareness groups (Pokdarwis) in the regions selected as the best tourist areas. The choice of the best tourism area is done in the first year research with survey method. Ngagagan tourism village was chosen as a pilot tourism village. Some of the achievements that have been obtained by the tourism village of Nglagheran are among the best tourism villages in ASEAN.

Direct observation was carried out by a research team in the tourism village of Ngagagan. Observations were made to see directly the process of village tourism care, Pokdarwis behavior, and the role of the surrounding community in supporting tourism village areas. Observation results are used to support the data obtained from the interviews.

Based on the results of observations and interviews, researchers grouped the results of observations and interviews into 7 important themes. The seven important themes are; 1) The process of forming tourist villages tourism., 2) Government support for the development of villages. 3) The process of forming a tourism conscious group, 4) The role of key figures in Pokdarwis progress; 7) Management of tourism areas. The seven themes can be described as follows; 


\subsection{The process of forming a tourist village}

The formation of a tourism village originated from the community. Beginning with the initiative of the community, then the village head / lurah reported to the tourism departement, then they conducted a survey, after being assessed as worthy of the tourism office would give a decree setting a tourism village. After being established as a government tourism village, it provides support in the form of coaching, motivation (competition), and assisting in making the facilities needed (eg parking \& WC).

After the tourism village is established the tourism service will conduct an evaluation process. The evaluation is done by looking at the number of tourist visits. If tourist visits are considered not optimal, the tourism agency will provide support to increase the number of visits. One way to increase support is for example by holding a race in a tourist village. Tourism service support continues to be provided until local tourism awareness groups (Pokdarwis) are considered to have independently developed local tourism areas.

\subsection{Government support for tourism village development}

In the process of developing village tourism, the government plays a passive role. The government plays an active role after the initiative of the community to develop a tourism village. Villagers can report the establishment of a tourism village through the lurah. The government can also take a role if you see the achievements of youth and village communities. Early development of tourism villages, usually carried out independently by the community. In the process of developing tourism villages, Pokdarwis is usually supported by village funds and BUMD (village owned business entities). The government also provides support through the Rural Independent Community Empowerment Program (PNPM). PNPM funds are usually used by Pokdarwis to complete facilities in tourism areas.

In addition to being physical, government support can be conducted in the form of training. The training provided is related to proper management in managing tourism villages. The government also brings experts from various institutions to support the development of tourism villages.

\subsection{The process of pokdarwis formation}

The beginning of the formation of Pokdarwis in the tourism village of nglaghelaran, due to the initiative of one of the village youth. This village youth became a key figure who mobilized youth cadets to actively form a tourism management agency. Key figures have high creative power and are able to see tourism potential in the tourism village nglaghelaran. When youth organization (Karang Taruna) was active, a local village Pokdarwis was formed.

Socialization of Pokdarwis formation was carried out at local village events, for example: kenduri, pengajian and village meetings. After the community understands the function of pokdarwis formation, community support for tourism village development begins to flow.

The active role of the community in developing Pokdarwis makes the village of tourism are able to develop. After funding flows and help

\subsection{The role of key figures in Pokdarwis progress}

Key figures have an important role for the beginning of the formation of Pokdarwis in the tourism village of Nglaghelaran. Initiatives from key figures are able to move Karang Taruna 
to actively develop village tourism potential. In the initial phase of the tourism village establishment, key figures have an important role in educating the local community to want to support the development of the tourism village. In the initial phase of the establishment of a tourist village, many people will be skeptical and apathetic. Especially in rural communities where most of their citizens have low education. Key figures must be able to mobilize a group of villagers who are aware and have the same ideals, to develop a tourist village. When the tourism village has developed, and the number of tourists is increasing, the community will be more easily asked to provide support for the development of the village.

\subsection{Planting the value of sapta charm}

Planting the value of sapta charm is done in a simple way. The application of the value of Sapta charm in society every time there is a kenduri event (Javanese customary safety ceremony), worship services such as Maulid Nabi and religious lectures. The point is the cultivation of sapta values of charm is given in conjunction with village events, which are attended by all villagers.

The value of sapta charm that is instilled in the community is among others; clean lifestyle, preservation of the natural environment, and friendliness to tourists. There is no specific module in delivering sapta charm values. The speaker only delivers the material in a simple manner.

The application of the Sapta charm value is also carried out by applying several regulations. For example the rules for dressing neatly, not tattooed and long haired. Community members who want to fulfill the appearance rules will be involved in managing tourism objects. Involvement in managing tourism objects will get rewards for honorarium.

Another example of applying values by enforcing rules for example, is not allowed to throw cigarette butts carelessly. If there are people who throw cigarettes carelessly, they will be punished. Punishment for those caught throwing cigarettes carelessly is not a fine in the form of money, but a dedicated work to clean up the tourist area.

\subsection{Financial management of tourist attractions}

The financial management system is one of the important factors in supporting the sustainability of tourism objects. Management of income from entry tickets must be managed professionally and transparently. Transparent management makes all parties involved can trust each other.

Pokdarwis members who participate in managing tourist attractions get a salary. There is a salary level for Pokdarwis managers. Daily salary given for daily tasks of Rp 50,000 - Rp. 80,000. Salaries are given every week. The existence of a payroll system, making people interested in making Pokdarwis activities as a side business.

\subsection{Tourism area marketing management}

There are various ways used by Pokdarwis to market tourist attractions that it manages. One of them introduces the potential of the region with competitions and blogs. The manager also invites guests to plant trees, so that guests have the desire to look back at the plants he has planted. 


\section{References}

[1] P. Gelge., I., Industri Pariwisata Indonesia dalam Globalisasi Perdagangan Jasa. Bandung: PT Refika Anditama, 2006.

[2] Lawson, Fred, \& Baud-Bovy. (1997). Tourism and Recreation Development. CBI Publishing Company, Inc : Boston.

[3] Robinson, H. (1976). A Geodraphy of Tourism. London :Mc Donald

[4] Sugiyono (2007). Metode Penelitian Pendidikan Pendekatan Kuantitatif, Kualitatif dan R\&D. Bandung : Alfabeta 